\title{
WSPÓŁCZESNE PRZEMIANY ZACHOWAŃ WYBORCZYCH JAKO EFEKT KSZTAŁTOWANIA SIĘ NOWYCH PODZIAŁÓW SOCJO-POLITYCZNYCH
}

\author{
CONTEMPORARY CHANGES IN ELECTORAL BEHAVIOR \\ AS A RESULT OF SHAPING NEW SOCIAL CLEAVAGES
}

Jakub Potulski*

\begin{abstract}
ABSTRAKT
Transformacja współczesnego społeczeństwa związana z przejściem do tzw. społeczeństwa informacyjnego skutkuje kształtowaniem się nowych podziałów społecznych. Można wskazać na kilka najważniejszych linii podziałów i konfliktów oraz na ich polityczne konsekwencje. $\mathrm{W}$ artykule autor stara się wskazać najważniejsze podziały społeczne politycznie doniosłe (social cleavages), które są efektem dwóch „ponowoczesnych” rewolucji: „postindustrialnej” i „postnarodowej”. Analiza nowych podziałów socjo-politycznych pozwala na lepsze zrozumienie sukcesów ruchów antyestablishmentowych.
\end{abstract}

Słowa kluczowe: podział socjopolityczny; system partyjny; społeczeństwo informacyjne; konflikty polityczne
Transformation of our society creates new social cleavages. There are a number of significant social cleavages and political conflicts within the information society. In the article, the author tries to identify the most important social cleavages that will emerge as a result of two "postmodern" revolutions: the "postindustrial" and "postnational" one, and also tries to analyse its political consequence. As an effect of "postindustrial revolution" we can observe the cleavage between the primary and secondary economy and cleavage between social class formed by the people suffering from precarity and social class which benefited from economic globalization. As an effect of "postnational revolution" we can observe cleavage between localist and cosmopolitan identities or hybrid identity vs. traditional identity. These cleavages influence the contemporary existing political relationship within political parties.

Keywords: social cleavages; party system; information society; political conflicts

* Uniwersytet Gdański, Wydział Nauk Społecznych. 


\section{WSTĘP}

Jednym $\mathrm{z}$ wiodących tematów pojawiających się w ostatnich latach w dyskusjach przedstawicieli nauk społecznych jest problem zmian zachodzących we współczesnym społeczeństwie. Żyjemy w czasach między dwiema epokami: industrialną i informacyjną. Prognozowane nadejście społeczeństwa informacyjnego związane jest $\mathrm{z}$ kompleksową rekonstrukcją struktur i instytucji społecznych. Szybko postępująca transformacja naszej rzeczywistości społecznej stanowi wyzwanie dla nauk o polityce, gdyż złożony i kompleksowy charakter zachodzących przemian powoduje trudności z adekwatnym wyjaśnianiem procesów zachodzących w sferze polityki. Nie bardzo wiemy, czym będzie „dojrzałe” społeczeństwo informacyjne i wciąż jest więcej pytań niż racjonalnych odpowiedzi na pojawiające się wątpliwości. Tempo zmian gospodarczych, społecznych i technologicznych jest zbyt duże. Możemy za to obserwować wiele przejawów związanych z przejściem do społeczeństwa informacyjnego i próbować „wtłoczyć” je w pewne schematy analityczne, tak aby nadać pewien sens otaczającej nas rzeczywistości społecznej. Jedno wydaje się być pewne, że obecna transformacja cywilizacji przemysłowej w informacyjną spowoduje głębokie i wszechstronne przemiany egzystencji społecznej, podobnie jak miało to miejsce przy przejściu od cywilizacji rolniczej do przemysłowej. W efekcie tych zmian ukształtuje się „nowe” społeczeństwo ze specyficznymi sposobami organizacji życia społecznego, politycznego i gospodarczego. Dla politologii najważniejsze jest pytanie o to, jak będzie wyglądać sfera polityczności w kształtującym się społeczeństwie informacyjnym.

\section{TEORIA PODZIAŁÓW SPOŁECZNYCH (SOCIAL CLEAVAGES)}

Transformacja związana z kształtowaniem się społeczeństwa informacyjnego oznacza przemiany struktury społecznej i tym samym pojawienie się nowych linii podziałów społecznych oraz związanych z nią konfliktów. Konflikty związane z kształtowaniem się społeczeństwa informacyjnego mogą ulec polityzacji, wpływając na charakter rywalizacji politycznej. Poszukując odpowiedzi na pytanie, czy możemy obserwować obecnie pojawienie się nowych linii rywalizacji politycznej odzwierciedlających procesy związane z ewolucją naszych społeczeństw, można sięgnąć do jednej z najbardziej wpływowych teorii wyjaśniających dynamikę funkcjonowania sfery polityki, jaką jest rokkanowska teoria podziałów społecznych politycznie doniosłych (social cleavages). Mimo tego, że 
powstała w latach sześćdziesiątych, teoria ta jest wciąż źródłem inspiracji dla wielu badaczy próbujących zrozumieć i wyjaśnić źródła konfliktów politycznych oraz dynamikę systemów partyjnych, a jej możliwości heurystyczne wykraczają poza problematykę podziałów występujących w ramach systemów partyjnych. Docenienie analitycznych możliwości teorii Rokkana spowodowało, że od lat zajmuje ona centralną rolę w literaturze poświęconej europejskim systemom politycznym i współczesnym zachowaniom politycznym. O niesłabnącym zainteresowaniu świadczą kolejne prace i artykuły, odwołujące się do rokkanowskiej koncepcji cleavages (por. Karvonen, Kuhnle, 2001, s. 334).

Norweski politolog Stein Rokkan $(1962,1967)$ głównym obszarem swoich zainteresowań naukowych uczynił problem zachowań wyborczych. W trakcie swoich badań akademickich zainteresował się problemem historycznych studiów nad procesami tworzenia się politycznych ram, w ramach których głosujący podejmują decyzję. Zwrócił on uwagę na znaczenie historii dla zrozumienia korzeni współczesnych mu podziałów i różnic politycznych ukształtowanych w powojennych europejskich systemach partyjnych. Badał on źródła podstawowych podziałów (cleavage) ekonomicznych, społecznych i politycznych, i wkrótce powstały jego porównawcze studia poświęcone ukształtowaniu się podstawowych podziałów społecznych oraz historycznej analizie ich kształtowania się w poszczególnych krajach Europy Zachodniej. Teoria podziałów społecznych stała się popularna dzięki napisanej wspólnie z Seymourem Lipsetem pracy Party Systems and Voter Aligments: Cross-National Perspective (1967).

Teza Rokkana brzmiała: istnieją zjawiska zachodzące na poziomie makro, które w największym stopniu wpływają na strukturę społeczną i podziały socjoekonomiczne. Kształtujące się podziały scojoekonomiczne znajdują swoje odbicie w strukturze podziałów politycznych, a przede wszystkim w ramach systemów partyjnych. Badania prowadzone przez Rokkana i Lipseta były związane z próbą wyjaśnienia stabilności zachodnioeuropejskich systemów partyjnych i lojalności wyborczych. Słynna stała się hipoteza „zamrożenia”, która została sformułowana jako wyjaśnienie trwałości podziałów politycznych, które w zachodnioeuropejskich systemach partyjnych bazowały na tych samych podziałach politycznych, które ukształtowały się pół wieku wcześniej, niezależnie od wydarzeń związanych z wyzwaniem, jakie pojawiło się ze strony komunizmu i narodowego socjalizmu. Fakt ten czynił badanie społecznej bazy podziałów politycznych atrakcyjnym zadaniem badawczym.

Koncepcja podziałów społecznych politycznie doniosłych zakładała, że fundamentalną podstawą zjawisk politycznych są długotrwałe procesy ewolucji 
struktury społecznej. W szczególności oznacza to, że podziały w strukturze społecznej stanowią podstawę systemu partii politycznych. Zgodnie z powszechnie akceptowaną obecnie definicją teoria social cleavages zawiera trzy podstawowe założenia: 1 . Społeczeństwa różnicują się na grupy według demograficznych lub socjoekonomicznych linii podziału; 2 . Wewnątrz tych grup istnieje wspólnie podzielana kolektywna tożsamość oraz wspólne wartości i postawy; 3. Istnieją także pewne organizacyjne formy wyrażania kolektywnej tożsamości, dzięki czemu możliwe jest podejmowanie działań zbiorowych (Bartolini, Mair, 1990, s. 213-220). W bardziej ogólnym sensie termin podziały społeczne politycznie doniosłe używany jest do opisu i analizy trwałych wzorów zachowań politycznych, łączących grupy społeczne z politycznymi organizacjami (Bornschier, 2009, s. 3).

Lipset i Rokkan podjęli próbę konceptualizacji związku pomiędzy wielkimi procesami historycznymi, podziałami w społeczeństwie a instytucjonalizacją systemu partyjnego i analizowali w perspektywie historycznej procesy demokratyzacji i kształtowania się systemów partyjnych, zachodzące w państwach Europy Zachodniej. Badacze argumentowali, że nowoczesne systemy partyjne w Europie Zachodniej zostały ukształtowane przez serię historycznych konfliktów związanych z budową państw narodowych, przemianami religijnymi i kształtowaniem się nowej struktury społecznej, które zachodziły w okresie pomiędzy Reformacją a rewolucją przemysłową. Zachodzące zmiany społeczne wywołały określone konsekwencje na płaszczyźnie politycznej. W pracy Party Systems and Voter Aligments: Cross National Perspectives Lipset i Rokkan, analizując funkcjonowanie zachodnioeuropejskich systemów partyjnych, przyjęli założenie, że społeczeństwo jako całość charakteryzuje się relatywnie stałymi podziałami (cleavages), partie polityczne zaś zasadniczo odzwierciedlają te podziały i reprezentują związane z nimi interesy na arenie politycznej (Lipset, Rokkan, 1976, s. 123). Autorzy ci opisali cztery podstawowe podziały socjopolityczne w ramach struktury społecznej, które prowadzą do konfliktu grup interesów oraz rywalizacji partii politycznych w ramach systemu partyjnego. Podziały te związane były z następującymi konfliktami: 1) kultura lokalna versus kultura dominująca; 2) kościół versus scentralizowane państwo; 3) dominujący (primary economy) versus wtórny (secendary economy) sektor gospodarki; 4) pracodawcy versus pracobiorcy.

Podziały te były efektem dwóch rewolucji związanych z europejską nowoczesnością: narodową i przemysłową. Rewolucje te przyczyniły się do ukształtowania się krytycznych linii podziałów społecznych (social clavages), gdyż 
procesy modernizacyjne wywołane przez rewolucję przemysłową i narodową wywoływały opór i kontrmobilizację grup zagrożonych procesami zmian cywilizacyjnych. Produktem tego, co określone zostało jako rewolucja narodowa, był konflikt pomiędzy kultura centralna związana $z$ budowaniem państwa narodowego a nasilającym się oporem grup podległych, odmiennych pod względem etnicznym, językowym lub religijnym, znajdujących się na prowincji i peryferiach kraju; konflikt pomiędzy centralizującym, standaryzującym i mobilizującym państwem narodowym a historycznie utrwalonymi korporacyjnymi przywilejami Kościoła. Dwa z tych podziałów to produkty rewolucji przemysłowej: konflikt pomiędzy interesami właścicieli ziemskich a powstającą klasą przedsiębiorców przemysłowych; konflikt pomiędzy właścicielami i pracodawcami z jednej strony a dzierżawcami, pracownikami rolnymi i robotnikami z drugiej.

Analizując systemy partyjne krajów zachodnioeuropejskich lat sześćdziesiątych, Lipset i Rokkan doszli do wniosku, że odzwierciedlają one podziały społeczne, które ukształtowały się ponad pół wieku wcześniej, a alternatywy partyjne i lojalności wyborcze są starsze niż większość elektoratu narodowego (Lipset, Rokkan, 1967, s. 138). Na tej podstawie sformułowali oni twierdzenie o „Zamrożonych systemach partyjnych”. „Zamrożenie” oznacza ukształtowanie się stabilnych powiązań pomiędzy partiami politycznymi i podziałami socjopolitycznymi, które występują w strukturze społecznej (Mair, 1997, s. 27-44). Rokkanowska „hipoteza zamrożenia”, zakładająca, że głęboko utrwalone podziały społeczne stabilizują zachowania wyborcze i redukują wyborczą niestabilność, stała się słynna i wzbudziła duże zainteresowanie badaczy.

Parę lat po ukazaniu się pracy Lipseta i Rokanna ich analizy zostały potwierdzone przez badania empiryczne. Rose i Urwin (1970, s. 287-319) w artykule Social Cohesion, Political Parties, and Strains in Regimes empirycznie udokumentowali fakt, że lojalność wyborcza wobec partii politycznych w zachodnioeuropejskich systemach partyjnych ulega niewielkim zmianom i pozostaje stabilna przez dziesięciolecia, a nawet przechodzi na kolejne generacje. M. in. dzięki temu teoria Lipseta i Rokkana na wiele lat zdominowała badania nad zachowaniami wyborczymi. Stała się ona pewnym uniwersalnym modelem, który był szeroko stosowany w analizach systemów partyjnych w liberalnych demokracjach.

Problemem był fakt, że praca Rokkana i Lipseta, która ukazała się pod koniec lat sześćdziesiątych, szybko zaczęła tracić na aktualności. Już w latach siedemdziesiątych zaczęto prowadzić badania, które podważały rokkanowskie twierdzenie o „zamrożeniu” systemów partyjnych. W wielu pracach zaczęto udowadniać, że tradycyjne związki pomiędzy grupami społecznymi a partiami 
politycznymi tracą na swoim znaczeniu (por. Dalton, 1984, s. 264-284; Dalton, Flanagan, Beck, 1984; Franklin, 1985; Clark, Lipset, 1991, s. 397-410; Clark, Lipset, Rempel, 1993, International Sociology, s. 293-316; Franklin, Mackie, Valen, 1992; Nieuwbeerta Ultee, 1999, s. 123-160; de Graaf, Heath, Need, 2001, s. 1-15; Knutsen, 2006). O ile Rokkan i Lipset w swojej pracy skupili swoją uwagę przede wszystkim na zagadnieniu, w jaki sposób doszło na przestrzeni wieków do powstania, a następnie do „zamrożenia” zachodnioeuropejskich systemów partyjnych, o tyle kolejne prace poświęcone temu zagadnieniu koncentrowały się przede wszystkim na analizie trwałości „zamrożonych” podziałów.

Empiryczne obserwacje zachowań wyborczych wskazywały na coraz łatwiejsze i szybsze przenoszenie się przez wyborców pomiędzy partiami, znaczny wzrost liczby wyborców nie do końca zdecydowanych i podejmujących decyzję w ostatniej chwili, pojawienie się tzw. partii protestu oraz powstanie i rozwój ugrupowań reprezentujących nowy typ konfliktu politycznego związanego $\mathrm{z}$ rozprzestrzenianiem się tzw. wartości postmaterialistycznych. Słynne stały się zwłaszcza badania Ronalda Ingleharta (1977), który na podstawie szeroko prowadzonych badań empirycznych zwrócił uwagę na fakt, że zmiany zachodzące w postawach politycznych wyborców mogą być skutkiem „milczącej rewolucji” (silent revolution), która jest związana z głęboką przemianą w systemach wartości nowych pokoleń wchodzących w życie. Coraz częściej zaczęto podkreślać, że nastąpił koniec polityki partyjnej opartej na podziałach społecznych politycznie doniosłych w rozumieniu Lipseta i Rokkana. Spowodowało to, że ponownie przed badaczami stanął problem wyjaśnienia źródeł lojalności partyjnych. Jeżeli lojalności wyborcze nie kształtują się już dłużej na podstawie podziałów w strukturze społecznej ukształtowanych w poprzednim stuleciu, to jakie to ma konsekwencje dla współczesnych przemian sfery polityki i od czego zależą współczesne lojalności i decyzje wyborcze?

Jedną z możliwych odpowiedzi na to pytanie jest stwierdzenie, że zmiany zachodzące w ostatnich dekadach dwudziestego wieku doprowadziły do daleko idących zmian w strukturze społecznej, a współcześnie liderzy polityczni stanęli przed wyzwaniem związanym z koniecznością zagospodarowania kształtujących się nowych linii podziałów społecznych, które odgrywają taką samą rolę we współczesnej polityce jak podziały analizowane przez Lipseta i Rokkana w latach sześćdziesiątych. Tego typu interpretacja pozwala na redefinicje klasycznej koncepcji podziałów społecznych politycznie doniosłych i dostosowanie jej do realiów współczesnego świata. Analiza przemian struktury społecznej, wyłanianie się nowych podziałów społecznych i ich wpływu na aktywność polityczną 
obywateli wydaje się być ważnym zadaniem badawczym, pozwalającym na wyjaśnienie procesów zachodzących we współczesnej sferze polityki.

\section{PROBLEM BADAWCZY I HIPOTEZY}

Stopniowe zanikanie polityki i zachowań wyborczych opartych na podziałach wskazanych przez Lipseta i Rokkana spowodowało, że zakwestionowano ich trwałość w warunkach współczesnego świata. Jednakże badania empiryczne, podważające hipotezę o „zamrożeniu” zachodnioeuropejskich systemów partyjnych, nie oznaczają, że rokkanowska teoria podziałów społecznych politycznie doniosłych jest błędna. Siła tej koncepcji tkwiła między innymi w jej zdolności do logicznego łączenia indywidualnych zachowań politycznych (mikro poziom) z wielkimi procesami historycznymi (makro poziom). Założenia teoretyczne przyjmowane przez Lipseta i Rokkana są na tyle uniwersalne, że można podjąć próbę wykorzystania ich do analizy współczesnych trendów zachodzących $\mathrm{w}$ postawach politycznych i systemach partyjnych w wysoko rozwiniętych krajach.

Fundamentalne zmiany społeczne, które zaszły w ostatnich dekadach dwudziestego wieku, spowodowały, że trudno oczekiwać trwania tych linii podziałów społecznych politycznie doniosłych, o których pisali Lipset i Rokkan. W niniejszym artykule autor założył, że analizy Rokkana i Lipseta dotyczące podziałów socjopolitycznych, strukturyzujących zachodnioeuropejskie systemy polityczne straciły już swoją aktualność. Nie mniej jednak sam model teoretyczny zaproponowany przez tych uczonych wciąż jest dobrym narzędziem analitycznym, służącym do wyjaśniania procesów zachodzących w ramach systemów partyjnych. Warto analizować zachodzące obecnie zjawiska społeczno-polityczne „w duchu” rokkanowskiej teorii podziałów socjopolitycznych, gdyż jest to wciąż użyteczne narzędzie analityczne, posiadające duże znaczenie heurystyczne.

Zgodnie z założeniami modelu Lipseta i Rokkana podziały polityczne (cleavage) mają swoje źródło w transformacji struktury społecznej wywołanej przez makropoziomowe procesy. W chwili, gdy social clavages zostają wykorzystane do mobilizacji politycznej i dokonuje się ich instytucjonalizacja w ramach systemu partyjnego, tworzą się silne sojusze i lojalności polityczne, które są reprodukowane, aż do momentu, w którym dokona się kolejna transformacja struktury społecznej. Autor artykułu przyjął hipotezę, że mamy obecnie do czynienia z transformacją struktury społecznej związaną z przejściem od społeczeństwa 
przemysłowego do społeczeństwa informacyjnego. Transformacja ta kreuje nowe podziały socjopolityczne. Wykorzystując istniejący schemat analityczny, podjął próbę identyfikacji współczesnych makroprocesów, które według niego, w największym stopniu wpływają na przemiany struktury społecznej i w największym stopniu strukturyzują podziały na scenie politycznej.

Wykorzystując rokkanowski model kształtowania się podziałów społecznych politycznie doniosłych, można przyjąć, że także współczesna głęboka transformacja życia gospodarczego i społecznego związana z drugą rewolucją przemysłową (informatyzacja, automatyzacja, robotyzacja) oraz z procesami globalizacji i transnacjonalizacji, napędzanymi przez postęp technologii informacyjnych, będzie miała swoje odzwierciedlenie w strukturze społecznej, a tym samym w zachowaniach politycznych. Oznaczałoby to, że mamy do czynienia z erozją linii podziałów społecznych ukształtowanych w epoce nowoczesności i kształtowaniem się nowych granic i barier w strukturze społecznej.

Europa Zachodnia początku dwudziestego pierwszego wieku przeżywa proces określany niekiedy jako „nadejście cywilizacji III fali”, czyli cywilizacji informacyjnej. Podobnie jak miało to miejsce w dziewiętnastym wieku, także i obecnie mamy do czynienia $z$ dwiema rewolucjami będącymi efektem zachodzących zmian cywilizacyjnych: postnarodowa i postindustrialna. Te dwie rewolucje, podobnie jak i przedtem rewolucja narodowa i przemysłowa, są źródłem głębokich zmian społecznych, a tym samym prowokują także opór i kontrmobilizację wobec nadchodzącego „nowego ładu”; ładu globalnego, postnarodowego, postindustrialnego.

Autor przyjął hipotezę, że to właśnie te procesy kreują dziś najbardziej znaczące podziały polityczne, które znajdują swoje odzwierciedlenie w systemach partyjnych i zachowaniach wyborczych. Aby empirycznie sprawdzić jakość swojej hipotezy, autor podjął próbę przetestowania rokkanowskiego modelu we współczesnych warunkach i zaproponowanej przez siebie interpretacji klasycznej teorii social cleavages na przykładzie wyborów prezydenckich w USA. Przyjął założenie, że wybory w USA stanowią interesujące studium przypadku (case study), które pozwala na ukazanie, w jaki sposób kształtują się ponowoczesne podziały polityczne i jakie maja one konsekwencje dla zachowań wyborczych. 


\section{SPOŁECZEŃSTWO INFORMACYJNE I NOWE PODZIAŁY SOCJOPOLITYCZNE}

Dość powszechne jest obecnie przekonanie, że pod koniec dwudziestego wieku przeżyliśmy jeden z rzadkich historycznych zwrotów - transformację naszej „kultury materialnej” pod wpływem nowego technologicznego paradygmatu, zorganizowanego wokół technologii informacyjnych (por. Castells, 2007, s, 78-84). Rewolucja technologiczna, skoncentrowana wokół technik informacyjnych, przeobraża nie tylko materialne podstawy społeczeństwa, ale także prowadzi do gwałtownych przemian społecznych i kształtowania się nowej formy życia społecznego, określanej mianem „cywilizacji informacyjnej” (por. Szewczyk, 2007, Białobocki, Moroz, Konopka, Zacher, 2006; Krzysztofek, Szczepański, 2005; Doktorowicz, 2002). Niezależnie od kontrowersji związanych ze zbyt pośpiesznym ogłaszaniem nadejścia nowej epoki społeczeństwa informacyjnego można przyjąć, że prognozowane nadejście epoki informacyjnej będzie skutkowało głębokimi zmianami w strukturze społecznej, a tym samym kształtowaniem się nowych linii podziałów społecznych.

Przejście od społeczeństwa nowoczesnego do informacyjnego związane jest z dwoma procesami makrospołecznymi o znaczących konsekwencjach społeczno-politycznych: rewolucja postnarodowa i rewolucja postindustrialną. Czym one są i jakie są ich polityczne konsekwencje?

Rewolucja postindustrialna ${ }^{1}$ związana jest z pojawieniem się rozwiązań technologicznych, które doprowadziły do kolejnej „rewolucji przemysłowej”. Wprowadzenie w 1969 r. programowalnego sterownika logicznego Modicon 084 otworzyło erę automatyki przemysłowej i robotyzacji. Skonstruowanie w 1971 r. pierwszego mikroprocesora Intel 4004 otworzyło erę informatyzacji. Robotyzacja, automatyzacja i informatyzacja doprowadziły do gwałtownych zmian w strukturze gospodarki. Zmiany technologiczne w połączeniu z decyzjami politycznymi dotyczącymi liberalizacji gospodarczej w sakli całego świata wywołały głęboką transformację instytucji gospodarczych. Kluczowymi elementami kształtującego się nowego modelu gospodarczego stały się głęboka integracja lokalnych gospodarek z gospodarką globalną, przesunięcie wiodących

1 Jednym z pierwszych badaczy, który zwrócił uwagę na znaczenie rewolucji telekomunikacyjnej dla przemian społeczno-gospodarczych, był Daniel Bell, który w opublikowanej w 1974 r. pracy The Coming of Post-Industrial Socjety ogłaszał nadejście nowego poprzemysłowego społeczeństwa i analizował główne kierunki zmian, którym podlegały gospodarki i społeczeństwa zachodnioeuropejskie. 
światowych gospodarek od wytwórczości do usług (deindustrializacja), a także entuzjastyczne wprowadzenie nowoczesnych technologii, często postrzegane jako narodziny "gospodarki opartej na wiedzy - GOW” (knowledge economy). Skutkiem procesów globalizacji gospodarczej stało się także umiędzynarodowienie produkcji i usług, postępująca globalizacja produktów, firm i rynków oraz ukształtowanie się nowego międzynarodowego podziału pracy (new international division of labor - NIDL).

Kształtowanie się GOW oraz NIDL to dwa główne elementy związane $\mathrm{z}$ rewolucją postindustrialną. W przypadku GOW jest to porządek ekonomiczny, w którym wiedza, a nie praca, surowce czy kapitał są kluczowym zasobem. GOW posiada następujące nośniki: przemysł wysokiej technologii, usługi społeczeństwa informacyjnego, usługi nasycone wiedzą i edukacją. Powstanie GOW oznacza po pierwsze „zmierzch przemysłu” (udział produkcji przemysłowej w PKB zaczyna spadać w krajach wysokorozwiniętych). Po drugie wyraźnie widać deindustrializację oznaczającą upadek tradycyjnych branż i rodzajów działalności gospodarczej. Po trzecie zaczyna obowiązywać nowy paradygmat rozwoju: zaawansowane technologie i usługi, który zastępuje fordowsko-taylorowski przemysłowy model rozwoju. Po czwarte rośnie rola usług jako wiodącego obszaru biznesu i pracy (service economy; por. Kotowicz-Jawor, 2009; Kukliński, 2003, 2001).

W przypadku NIDL można dostrzec, że przekraczanie granic przez narodowe systemy produkcyjne za pomocą czy to inwestycji bezpośrednich, czy międzynarodowej subkontrakcji, pogłębiło wzajemne zależności i funkcjonalną integrację gospodarki światowej. Korzyści z tej integracji są jednak dystrybuowane nierówno. Istotna część handlu światowego prowadzona jest nie za pomocą relacji czysto rynkowych, ale raczej wewnątrz przedsiębiorstw międzynarodowych lub przez takie formy organizacyjne, które łączą firmy w różnorodne sieci zwane globalnymi łańcuchami wartości. Najważniejszą rolę w takich globalnych łańcuchach wartości odgrywają tzw. firmy wiodące. Są one najczęściej ulokowane w krajach rozwiniętych. Należą do nich nie tylko międzynarodowi producenci, lecz także duzi sprzedawcy detaliczni czy markowi „producenci bez fabryk”. To firmy wiodące w globalnych łańcuchach decydują o tym, co ma być produkowane, w jaki sposób, kiedy i przez kogo. Analiza globalnej integracji gospodarczej prowadzona za pomocą globalnych łańcuchów wartości pokazuje, że dla wielu firm uzyskanie dostępu do rynków międzynarodowych nie polega wcale na projektowaniu, wytwarzaniu i marketingu nowych produktów. Zamiast tego celem jest uzyskanie dostępu do międzynarodowych sieci składających się z wielu różnych firm, między które są podzielone działania w zakresie projektowania, wytwarzania i marketingu. 
Procesy gospodarczej globalizacji oraz lokalnej deindustrializcji prowadzą do ujawnienia się nowych linii podziałów socjopolitycznych. Dualny charakter gospodarki (nowoczesny globalny sektor TNC's i tradycyjny sektor przedsiębiorstw krajowych zmuszony do konkurowania z konkurencją ze strony krajów bazujących na taniej sile roboczej) powoduje, że można wskazać na opozycję pomiędzy regionami z gospodarka postindustrialna (primary economy) i regionami z gospodarka industrialna (secondary economy). Interesy tych dwóch obszarów są odmienne (tak samo, jak podczas rewolucji przemysłowej odmienne były interesy miasta i wsi), stąd też obecna popularność politycznych haseł „odzyskania kontroli nad gospodarką" i „gospodarczego patriotyzmu”, związanych z ochroną tych gałęzi tradycyjnych przemysłu, które w największym stopniu dotknęły procesy gospodarczej globalizacji i przenoszenia produkcji do regonów o niższych kosztach produkcji.

Drugą linią podziału stworzoną przez rewolucję postindustrialna jest podział pomiędzy wysoko wykwalifikowaną postindustrialna siła roboczą, funkcjonująca w ramach elastycznych technik organizacji pracy, a sprekaryzwanymi grupami społecznymi, dla których automatyzacja, robotyzacja i ucieczka miejsca pracy do regionów o niższych kosztach oznacza brak stabilności zawodowej i brak miejsca na rynku pracy. Procesy transformacji rynku pracy (polaryzacja i uelastycznienie) mogą prowadzić do powstania tzw. globalnego prekariatu, składającego się z wielu milionów ludzi na całym świecie, pozbawionych stabilnego punktu zaczepienia. Można przyjąć, że różnice w pozycji na rynku mogą prowadzić do pojawienia się grupy ludzi o wysokich kwalifikacjach mających szansę na stabilne zatrudnienie i dużej grupy ludzi żyjacych $w$ sytuacji braku stabilizacji zawodowej (prekariat), a tym samym w poczuciu zagrożenia².

W przypadku dziewiętnastowiecznej rewolucji przemysłowej podziały o podłożu ekonomicznym, zwłaszcza zaś podział na pracobiorców (proletariat) i pracodawców, najsilniej strukturyzowały scenę polityczną i posiadając dużą siłę mobilizacyjną, okazały się być najbardziej trwałe. W przypadku współczesnych zmian najprawdopodobniej podziały odwołujące się do miejsca w systemie

2 Istotnym problemem może okazać się także fakt, że tzw. przemysł 4.0, wysoce zautomatyzowany i zrobotyzowany, będzie oznaczał ograniczenie dostępnej na rynku pracy, a tym samym podważał stabilność i bezpieczeństwo społeczne związane z zatrudnieniem. Problem ten był poruszany m.in. przez Jeremiego Ryfkina w książce Koniec pracy. Schyłek siły roboczej i początek ery postrynkowej (wyd. polskie Wrocław 2001). Niezależnie od kontrowersji związanych z pracami Ryfkina ewolucja, która dokonuje się obecnie w przemyśle może zachwiać podstawami obecnego systemu zatrudnienia, a tym samym wygenerować nowe konflikty społeczno-polityczne. 
produkcji (człowieka lub regionu) nie będą miały aż tak dużej siły mobilizacyjnej. Natomiast mobilizacyjną rolę „klasycznych” podziałów klasowych przejmą podziały kształtujące się w wyniku rewolucji postnarodowej, dotykającej dwóch podstawowych filarów naszej egzystencji społecznej: instytucji politycznych oraz sfery tożsamości. Oznacza to, że główne linie konfliktów będą efektem podziałów społecznych wywołanych przez przemiany systemów wartości (silent revolution) oraz przez rewolucję postnarodową. To kultura i tożsamość kulturowa będą kształtowały podstawowe wzorce spójności, dezintegracji i konfliktów politycznych. Dominujące staną się konflikty polityczne nowego typu, których podstawowym źródłem są różnice kulturowe. Konflikty tego typu mają największy potencjał dla politycznej mobilizacji i będą najszybciej zagospodarowywane przez elity polityczne, budujące swoją bazę poparcia społecznego.

Rewolucja postnarodowa (denacjonalizacja), która kształtuje „kulturowe” podziały socjopolityczne jest związana z niezwykłą wręcz zdolnością nowych technologii do przełamywania wszelkich barier i granic zarówno tych fizycznych, jak i tych społecznych. Współdziałanie różnorodnych czynników technologicznych, politycznych, społecznych i ekonomicznych spowodowało, że cechą charakterystyczną rzeczywistości społecznej przełomu XX i XXI w. stało się to, że ludzie mogą wchodzić we wzajemne interakcje nie tylko na poziomie lokalnym, prowincjonalnym, państwowym czy nawet makroregionalnym, ale także w skali całej planety, która stała się „jednym miejscem” (Scholte, 2005, s. 60). Rewolucja postnarodowa jest konsekwencją takiego stanu rzeczy.

Transnacjonalizacja procesów społecznych, politycznych i gospodarczych wymusza zmianę instytucjonalną, gdyż budowane w epoce nowoczesnej państwa narodowe nie są w stanie radzić sobie z problemami ponowoczesnego świata. Transformacja państwa (układów instytucjonalnych) jest zjawiskiem kompleksowym i skutkować będzie globalną zmianą konfiguracji władzy i tożsamości. $\mathrm{W}$ wymiarze politycznym rewolucja postnarodowa przejawia się $\mathrm{w}$ tendencji do tworzenia supranarodowych ugrupowań polityczno-gospodarczych, przejmujących kompetencje dotychczasowych państw narodowych. W wymiarze społecznym rewolucja postnarodowa przyczyniła się do intensyfikacji kontaktów międzykulturowych i procesów kulturowej dyfuzji. Ułatwienia związane z globalnymi przepływami ludzi, obrazów i idei spowodowały mieszanie się cywilizacji (mesh of civilization) oraz kształtowanie się hybrydowych społeczeństw (wielokulturowych) i hybrydowych tożsamości indywidualnych, czerpiących z wielu źródeł i wielu praktyk kulturowych. Warto podkreślić, że współczesny ponowoczesny konflikt pomiędzy tym, co globalne (ujednolicające, homogenizujące), a tym, 
co regionalne (narodowe, różnicujące) jest bardzo podobny do nowoczesnego konfliktu pomiędzy tym, co narodowe (ujednolicające, homogenizujące), a tym, co lokalne (partykularne, różnicujące).

Potencjał mobilizacyjny rewolucji postnarodowej wynika z faktu, że dotyczy jednych z najważniejszych obszarów naszej egzystencji: dotyczy ona sposobu funkcjonowania instytucji politycznych - państwa, oraz kolektywnej i indywidualnej tożsamości. Jest ona związana $\mathrm{z}$ dwoma procesami dotyczącymi instytucjonalnego i tożsamościowego wymiaru naszego życia społecznego. Po pierwsze z rekonstrukcją stworzonej w dobie nowoczesności formy państwa, jaką było scentralizowane państwo narodowe. Na jego miejsce zaczynają pojawiać się nowe formy, określane niekiedy jako państwo-sieciowe, tworzone przez złożoną sieć interakcji między narodowymi państwami, współnarodowymi i ponadnarodowymi instytucjami, regionalnymi i lokalnymi samorządami, a nawet organizacjami pozarządowymi. W miarę, jak nasze społeczeństwa stają się coraz bardziej płynne i złożone, konieczne stało się wypracowanie nowych mechanizmów i metod rządzenia, które mniej opierałyby się na zhierarchizowanych instytucjach państwowych, zamazując tym samym różnicę między państwem a społeczeństwem, między tym, co globalne i lokalne. W ramach ponowoczesnych instytucji politycznych realizowany jest model zarządzania wielopoziomowego, obejmującego organy subpaństwowe, państwowe i ponadpaństwowe oraz aktorów rządowych i pozarządowych. Jest to nowy poliarchiczny system władzy, charakteryzujący się wielością źródeł autorytetu, a państwo narodowe jest tylko jednym z tych źródeł, w dodatku coraz częściej zastępowanym przez globalne sieci zarządzania (global governance).

Po drugie z rekonstrukcją wytworzonych w dobie nowoczesności form identyfikacji, określanych jako tożsamość narodowa na rzecz budowy tożsamości hybrydowej. Wolny przepływ towarów, ludzi i idei w skali całego globu powoduje, że społeczeństwa ludzkie stają się bardziej złożone, heterogeniczne, wielokulturowe. Konstruując swoje „ja”, napotykamy na wielość wzorców i bodźców płynących z coraz bardziej zróżnicowanego otoczenia. Nasza tożsamość społeczna stałą się wielowymiarowa i trudno jest dziś jednoznacznie wyznaczyć granicę między „my” a „oni”. Efektem tego jest, że obecnie terminy, takie jak „społeczeństwo”, „kultura” i „naród”, okazują się już bardzo mało precyzyjne - te trzy pojęcia nie są synonimiczne ani homogeniczne. Pojęcie hybrydowości ma oddawać istotę współczesnej tożsamości: zmiennej, posiadającej wiele źródeł i konstruowanej. Rewolucja telekomunikacyjna i będąca jej następstwem globalizacja stworzyły podstawy dla kształtowania się bardziej płynnego i sfrag- 
mentaryzowanego „ja”, zwłaszcza dla osób, które większość swojej aktywności społeczno-zawodowej spędzają w przestrzeni transnarodowej, w której różnorodne tożsamości łatwo się stykają. W globalnym świecie zdominowanym przez transnarodowe migracje i przepływy kulturowe dalsza hybrydyzacja wydaje się być nieuniknionym procesem. Na obecnym etapie swojego rozwoju społeczeństwo globalne jest podzielone na dwa światy. W pierwszym jednostka jest mobilna i z łatwością przemieszcza się w poprzek barier i granic. Jest to świat kosmopolityczny i eksterytorialny. W drugim jednostka jest wciąż ograniczona więzami lokalności, a doświadczenie izolacji jest potęgowane przez globalne przekazy medialne, wywołując frustrację i agresję.

Analizując konsekwencje rewolucji postnarodowej w kontekście kształtowania się nowych podziałów społecznych politycznie doniosłych, można wskazać na opozycję pomiędzy scentralizowanym państwem narodowym i jego „tradycyjnymi elitami krajowymi”, przywiązanymi do idei terytorialnej suwerenności i autonomii, oraz „kosmopolityczny elitami” nowego typu, operującymi w przestrzeni ponadnarodowej i oderwanymi od konkretnej lokalizacji terytorialnej. Ponadto można wskazać na opozycję pomiędzy „postnowoczesną hybrydową kulturą globalną a tradycyjnymi źródłami tożsami zakorzenionymi” w lokalnej kulturze. Część badaczy przewiduje, że czaka nas okres „postnacjonalizmu”: państwo narodowe stanie się przeżytkiem, a w jego miejsce powstaną inne formy lojalności i tożsamości Rzeczywista wielokulturowość pokona sztuczną jedność państwa narodowego (por. Appandurai, 2005, s. 234-255).

Niezależnie od tego, że tego typu stwierdzenia mogą być przesadzone, to konsekwencje nadchodzących zmian budzą obawy, niepokój i próbę ochrony istniejących instytucji i struktur. Zmieniająca się gwałtownie rzeczywistość generuje coraz to nowe przestrzenie dla konfliktów i dla podziałów społecznych. Wraz z falą przemian pojawia się też fala kontrmobilizacji, wytwarzana przez tych aktorów, którzy znajdują się w gorszym położeniu/warunkach dewaluowanych i/lub stygmatyzowanych przez dominującą logikę rewolucji postnarodowej. Przedmiotem kontestacji jest po pierwsze nowy porządek polityczny, na który składa się złożona sieć interakcji między narodowymi państwami, współnarodowymi i ponadnarodowymi instytucjami, regionalnymi i lokalnymi samorządami, a nawet organizacjami pozarządowymi. Po drugie przedmiotem kontestacji jest globalizacja kultury, której efektem jest hybrydyzacja tożsamości. Krytykowane są masowe przepływy ludności (migracje) z tzw. Południa do rozwiniętych krajów Północy oraz polityka multikulturalizmu. 


\section{CASUS AMERYKAŃSKICH WYBORÓW}

Zgodnie z hipotezą LIpseta i Rokkana kształtujące się podziały społeczne powinny mieć swoje odzwierciedlenie w podziałach politycznych, a przede wszystkim powinny mieć odzwierciedlenie w zachowaniach wyborczych i lojalnościach partyjnych. Ponowoczesne „rewolucje” powinny zatem wpływać na charakter konfliktów i rywalizacji zachodzących w ramach systemu partyjnego. Powinny pojawić się partie polityczne, które będą starały się „zagospodarować” kształtujące się nowe podziały społeczne i wykorzystać ich istnienie do budowy swojej pozycji na scenie politycznej. Czy można zatem potwierdzić obserwacjami empirycznymi hipotezę o tym, że nadchodząca epoka informacyjna oznacza erozję dotychczasowych linii podziałów społeczno-politycznych i ukształtowanie się nowych? Czy podziały wynikające $\mathrm{z}$ rewolucji postindustrialnej i postnarodowej są na tyle istotne, aby radykalizować system polityczny i zmuszać elity polityczne do uwzględniania ich przy budowie grup i koalicji wyborczych?

Wydaje się, że empirycznym potwierdzeniem faktu, że mamy obecnie do czynienia $z$ kształtowaniem się nowych podziałów społecznych politycznie doniosłych wywołanych przez rewolucję postnarodowa i postindustrialna jest rosnąca popularność tzw. „antyestablishmentowych” ruchów społeczno-politycznych i „antyestablishmentowych” polityków. Ich sukcesy są przejawem kontrmobilizacji i oporu przed zmianami związanymi z nadejściem cywilizacji informacyjnej. Fala kontrmobilizacji, której symbolem są sukcesy „populistycznych"3 partii i ruchów politycznych, występuje w całym świecie rozwiniętym, który jako pierwszy wchodzi w epokę postindustrialną. W przypadku rewolucji postnarodowej przedmiotem konfliktu i rywalizacji politycznej staje się to, co globalne, uniwersalizujące i homogenizujące, masowe przepływy ludności (migracje) z tzw. Południa do rozwiniętych krajów Północy oraz polityka multikulturalizmu. W przypadku „rewolucji postindustrialnej” przedmiotem kontestacji są procesy gospodarczej globalizacji oraz lokalnej deindustrializacji oraz polaryzacja rynku pracy i obniżenie standardu życia klasy średniej, spowodowana przez przebudowę porządku społecznego na taki, w którym liczebnie

3 Określenie "partie populistyczne" jest przede wszystkim dziennikarsko-propagandową próbą deprecjonowania sukcesów politycznych partii występujących ze sprzeciwem wobec dominującego konsensusu gospodarczo-politycznego. Nie powinno być stosowane w dyskursie akademickim (albo stosowane $\mathrm{z}$ umiarem), gdyż utrudnia racjonalną i obiektywną analizę przemian zachodzących w ramach systemów partyjnych. Stosowane bezkrytycznie traci swój pierwotny sens. 
dominują dwie grupy: osoby z wysokimi dochodami i osoby z relatywnie niskimi dochodami i ograniczonymi możliwościami.

Interesującym studium przypadku mogą być Stany Zjednoczone i zjawiska, które ujawniły się podczas elekcji prezydenckiej Donalda Trumpa. Wyborczy sukces Donalda Trumpa okazał się zaskoczeniem dla wielu komentatorów i polityków. Wygrał bowiem kandydat powszechnie uznany za kandydata antyestablishmentowego, który musiał mierzyć się tylko ze swoimi rywalami politycznymi z Partii Demokratycznej, ale także z niechęcią elit Partii Republikańskiej, której przedstawiciele niejednokrotnie dawali wyraz swojej niechęci wobec Donalda Trumpa, a niekiedy nawet wprost odmawiali głosowania na kandydata własnej partii. Do władzy doszła osoba, która swój apel polityczny zbudowała na krytyce amerykańskiego establishmentu politycznego, zarówno z Partii Demokratycznej, jak i Republikańskiej, z której ramienia startował. Donald Trump pokonał w wewnętrznej rywalizacji o nominację prezydencką doświadczonych i uznanych polityków republikańskich, takich jak Marco Rubio i Jeb Bush, a następnie w wyborach prezydenckich pokonał niezwykle doświadczoną polityk z ramienia Partii Demokratycznej - Hillary Clinton, będącą symbolem politycznego establishmentu.

Wyjaśnienie fenomenu, jakim jest popularność i sukces polityczny Donalda Trumpa, wymaga wielowymiarowej analizy. Dużą rolę odegrały koniunkturalne czynniki wewnętrznej amerykańskiej polityki, ale sukces Donalda Trumpa pozwala także dostrzec znaczenie kontekstu makropoziomowego, związanego z kształtowaniem się nowych podziałów społecznych politycznie doniosłych jako reakcji na procesy związane z kształtowaniem się społeczeństwa informacyjnego. Apel wyborczy Donalda Trumpa, który przyczynił się do jego sukcesu, stanowi odzwierciedlenie kształtujących się nowych podziałów społecznych politycznie doniosłych, niemieszczących się już w „klasycznej” dychotomii Republikanie vs. Demokraci. Jest też przykładem interesującej próby politycznego zagospodarowania nowych podziałów socjopolitycznych i budowy nowej „koalicji wyborczej”.

W programie politycznym Trumpa, który był prezentowany w trakcie kampanii wyborczej, zarówno podczas rywalizacji wewnątrzpartyjnej, jak i w rywalizacji prezydenckiej z Hillary Clinton, można dostrzec charakterystyczne elementy, które potwierdzałyby hipotezę o pojawieniu się nowych linii podziałów społeczno-politycznych, związanych z rewolucją postindustrialną i rewolucją postnarodową.

Po pierwsze Donald Trump bardzo mocno wyrażał sprzeciw wobec procesów gospodarczej globalizacji, która pociąga za sobą przenoszenie amerykańskich 
miejsc pracy i amerykańskiego bogactwa do innych krajów (Meksyk, Chiny), co powoduje pauperyzację klasy średniej oraz przynosi zyski jedynie wąskiej grupie menadżerów korporacji, bankierom i skorumpowanym politykom kosztem ubożejącej klasy średniej i kosztem ciężko pracujących Amerykanów. M.in. dlatego Donald Trump odniósł sukces w stanach położonych w regionie Wielkich Jezior (Michigan, Ohio, Pensylwania i Wisconsin), związanych z tradycyjnym przemysłem zagrożonym przez praktyki relokacji produkcji oraz offshoringu i outsorcingu. Stany te stanowiły niegdyś przemysłowe centrum USA, obecnie jednak muszą borykać się z negatywnymi konsekwencjami gospodarczej globalizacji świata dla tradycyjnego amerykańskiego przemysłu. Natomiast Hillary Clinton zdobyła popularność w stanach zachodniego wybrzeża USA, będących siedzibą nowoczesnych globalnych korporacji i przemysłu high-tech. Firmy te doskonale zintegrowane $\mathrm{z}$ globalną gospodarką (dominujące w łańcuchach produkcyjnych) czerpią korzyści z liberalnej globalizacji gospodarczej świata.

Trump, podkreślając bardzo mocno swój „gospodarczy patriotyzm”, winą za upadek i kłopoty takich stanów jak Michigan obarczył waszyngtońską elitę polityczną, która w imię swoich "globalnych” interesów sprzedaje bogactwo Ameryki za granicę, budując drapacze chmur w Chinach, podczas gdy fabryki w Michigan „umierają” (por. Trump, 2016). Zapowiadał audyt wszystkich umów handlowych, renegocjacji umowy NAFTA, wyrażał sprzeciw wobec umów, takich jak TTIP i zapowiadał wprowadzenie ceł na towary meksykańskie i chińskie w celu ochrony amerykańskiej gospodarki przed zalewem tanich towarów, a także przywrócenie „amerykańskich” miejsc pracy. Jego sukces polityczny wskazuje na fakt, że udało mu się zagospodarować politycznie podział, który kształtuje się pomiędzy „regionami z gospodarką postindustrialną (primary economy) i regionami z gospodarką industrialną (secondary economy)". W interesie regionów, w których zakorzeniła się innowacyjna gospodarka oparta na wiedzy, pozostaje dalsza gospodarcza globalizacja świata. Natomiast w interesie regionów, w których dominują tradycyjne gałęzie przemysłu, jest ograniczenie umów o wolnym handlu i ochrona tradycyjnych gałęzi przemysłu, i to one odwołują się do „gospodarczego patriotyzmu” i „ochrony lokalnych miejsc pracy”.

Po drugie Donald Trump w swoim apelu wyborczym odwoływał się do „prowincjonalnej” Ameryki i przekonywał wyborców, że jego podstawowym celem jest odbudowa Ameryki i przywrócenie godności „Zwyczajnym ludziom”, „przyzwoitym i ciężko pracującym”. Hasła wyborcze Trumpa, wokół których zbudował on swoją kampanię prezydencką: "We will bring back our jobs. We will make America wealthy again. We will make America strong again. We will make 
America safe again. We will make America great again", były skierowane głównie do przedstawicieli amerykańskiej prowincji, ponoszącej koszty globalizacji świata i niechętnej wobec „wartości postmaterialistycznych”, reprezentowanych głównie przez przedstawicieli środowisk wielkomiejskich. Trump podkreślał, że jego celem jest odbudowa Ameryki i przywrócenie godności „zwyczajnym ludziom”, „przyzwoitym i ciężko pracującym”, co w dużym stopniu skierowane było przede wszystkim do wyborców wywodzących się z amerykańskiej prowincji. Potwierdzeniem takiego stanu rzeczy wydają się być wyniki głosowania w amerykańskich wyborach prezydenckich, w których Hillary Clinton zdominowała wielkie miasta, a Donald Trump prowincjonalną Amerykę. Hillary Clinton wyraźnie pokonała Donalda Trumpa, praktycznie we wszystkich wielkich amerykańskich metropoliach. Kandydatka Demokratów wyraźnie górowała nad swoim kontrkandydatem w miastach powyżej 500000 mieszkańców. Natomiast mniejsze miasta oraz obszary wiejskie zdecydowanie poparły Donalda Trumpa (Urban and rural America...). Nawet w stanach uchodzących za bardzo konserwatywne, np. Teksas, Hillary Clinton uzyskała w wielkich miastach dużą przewagę nad Donaldem Trumpem (U.S. Census Bureau, 2019). Wśród białych mężczyzn zamieszkujących amerykańską prowincję różnica w procentowym poparciu między Donaldem Trumpem a Hillary Clinton wynosiła 72\% do 24\%, nawet wśród kobiet mieszkających na prowincji różnica między Trumpem a Clinton wynosiła ponad 28 punktów procentowych (Opinion Why Rural...; Rural America Lifted Trump...; Why Trump Won...; America's Urban-Rural...).

Charakterystyczne są chociażby wyniki głosowania w Pensylwanii, gdzie we wszystkich „wiejskich” hrabstwach zwyciężył Donald Trump. Natomiast Hillary Clinton bezwzględnie zwyciężyła w stolicy stanu - Filadelfii. Różnice w prowincjonalnych hrabstwach stanu sięgały ponad 50 punktów procentowych (np. Jefferson County: D. Trump 77,5\%, Hillary Clinton 18,6\%), natomiast w ośrodkach miejskich wygrała zdecydowanie Hillary Clinton: w Filadelfii (Philadelphia County) 82,3\% do 15,3\%, w Pittsburgu (Allegheny County) 55,9\% do $39,5 \%$ (Elections results...). Widać tu ogromny podział pomiędzy miastem (kulturą dominującą) a wsią (kulturą peryferyjną). Wielkie miasta, takie jak Nowy Jork, San Francisco, Seattle, Boston czy też Filadelfia stanowią „huby” globalizacji; multikulturowe, otwarte na przepływy ludzi, kapitału, towarów i idei. Wielkomiejska kultura preferuje wartości związane z otwartością i globalnością. Natomiast obszary wiejskie z poczuciem deprywacji i wykluczenia stają się obszarem kontestacji wobec dominujących globalnych wzorców kulturowych oraz źródłem separatyzmu i obrony wartości zakorzenionych w „tradycyjnych” 
wzorcach społeczno-kulturowych. Wydaje się, że kształtujący się podział między centrum a peryferiami to podział pomiędzy zglobalizowanymi, multikulturowymi megapolis a wsią i mniejszymi miastami, które w dużym stopniu pozostają na peryferiach globalnych sieci przepływów. Jest to podział pomiędzy ponowoczesnymi wzorcami kultury (kultura dominująca) a tradycyjnymi tożsamościami społecznymi.

Po trzecie Donald Trump budował swój apel polityczny w oparciu o krytykę polityki multikulturalizmu i na sprzeciwie wobec imigrantów, wykorzystując fakt, iż coraz większą siłę mobilizacyjną ma straszenie najazdem obcych kulturowo imigrantów, którzy podważają tradycyjne wartości społeczne i są źródłem przestępczości, a także zagrożenia terroryzmem. Jako kandydat na prezydenta Trump wypowiadał się szczególnie stanowczo przeciwko imigrantom. Zapowiadał budowę muru na granicy z Meksykiem i wydalenie $\mathrm{z}$ kraju od 2 do 3 mln nielegalnych imigrantów. Obarczał imigrantów z krajów muzułmańskich odpowiedzialnością za radykalizm i terroryzm, podkreślając, że są oni nosicielami wartości sprzecznych z wartościami cywilizacyjnymi świata zachodnioeuropejskiego. Są więc oni osobami „obcymi” kulturowo i zagrożeniem dla przetrwania „białej” Ameryki. Trump m.in. proponował w czasie kampanii wyborczej całkowity zakaz wjazdu do USA muzułmanów (por. Trump, 2016).

\section{ZAKOŃCZENIE}

Rokkanowski model wyjaśniania podziałów politycznych procesami makropoziomowymi wydaję się wciąż być przydatny dla analiz zjawisk zachodzących w ramach współczesnych systemów partyjnych, przynajmniej w krajach wysokorozwiniętych. Wydaje się, że dla wyjaśniania obecnych procesów związanych z przemianami zachodzącymi w sferze polityki niezbędne jest umiejscowienie ich w makropoziomowym kontekście rewolucji postnarodowej i rewolucji postindustrialnej i falą oporu wobec zmian społecznych wywołanych przez nie. Powstające nowe ruchy społeczne i partie polityczne starają się tworzyć nowe koalicje wyborcze, odwołując się do podziałów społecznych będących efektem przemian związanych z nadejściem cywilizacji informacyjnej. Niezależnie od różnic związanych ze specyfiką poszczególnych krajów można zauważyć, że w apelu politycznym wielu partii politycznych powtarza się kilka bardzo charakterystycznych motywów, takich jak sprzeciw wobec multikulturalizmu, imigracji i globalizacji, a także zdecydowany sprzeciw wobec dotychczasowego 
establishmentu i zapowiedź powrotu do „tradycyjnych wartości”, ,gospodarczego patriotyzmu” i „odzyskania kraju z rąk kompradorskich elit i przywrócenia go obywatelom". Ta powtarzalność pewnych motywów oznaczałaby, że istnieją pewne uniwersalne punkty odniesienia pozwalające na budowę więzi elit politycznych z elektoratem, niezależnie od czynników geograficznych, społecznych czy kulturowych. Prowokuje to analiz porównawczych i ukazania, na wybranych przykładach, cech charakterystycznych współczesnych tzw. antyestablishmentowych ruchów i prób „upolitycznienia” kształtujących się nowych podziałów społecznych.

Otwartym pytaniem pozostaje wciąż problem, na ile współczesne konflikty społeczne okażą się trwałe, czyli nabędą tożsamości aksjologicznej i organizacyjnej, aż po instytucjonalizację konfliktów w ramach systemu partyjnego. Casus amerykańskich wyborów prezydenckich i podjęta przez Trumpa próba budowy nowej koalicji wyborczej wydaje się potwierdzać, że nowe podziały społeczna mają duży potencjał mobilizacyjny, co z kolei może powodować, że elity polityczne będą próbowały wykreować na ich podstawie trwałe lojalności partyjno-polityczne. Nie są to jednak jeszcze konflikty na tyle zinstytucjonalizowane w sferze politycznej, żeby można było mówić o ich „zamrożeniu”. Widzimy jedynie pierwsze oznaki strukturyzacji tego systemu, zgodnie z założeniami teorii podziałów socjopolitycznych. Jednakże hipoteza mówiąca o tym, że mamy do czynienia z polityczną "falą kontrmobilizacji”, która jest efektem relacji na rewolucje postnarodowa i postindustrialną, powinna być potwierdzona solidnymi badaniami empirycznymi. Analiza wyborów w poszczególnych krajach i porównywanie ich wyników powinny dać empiryczne podstawy dla dalszych uogólnień. Brakuje jeszcze dłuższej perspektywy czasowej, która mogłaby pokazać, na ile obserwowane trendy są stałe, a na ile są fenomenem przejściowym. Obecna fala kontrmobilizacji jest rzeczywistością in statu nascendi i nie wiadomo, jakie będą jej konsekwencje. Otwarte pozostaje pytanie, czy nowe linie podziałów społecznych są fenomenem tymczasowym, związanym z okresem przejścia od cywilizacji przemysłowej do postindustrialnej, czy może utrzymają się one w dłuższej perspektywie i będą trwale strukturyzować scenę polityczną przyszłych społeczeństw informacyjnych. Podziały te mogą w długiej perspektywie czasowej nie okazać się na tyle trwałe, aby doprowadzić do ponownego „Zamrożenia” systemów partyjnych. 
BiBLIOGRAFIA:

America's Urban-Rural Divides. (2017). Pobrane z: www.economist.com/news/specialreport/21724129-mutual-incomprehension-between-urban-and-rural-americacan-border-malice-americas.

Appandurai, A. (2005). Nowoczesność bez granic. Kraków: Uniwersitas.

Bartolini, S., Mair, P. (1990). Identity, Competition and Electoral Availability: The Stabilization of European electorates 1885-1995. Cambrigde: Cambridge University Press.

Białobocki, T., Moroz, J., Konopka, M.N., Zacher, L. (red.). (2006). Społeczeństwo informacyjne. Istota, rozwój, wyzwania. Warszawa: Wydawnictwa Akademickie i Profesjonalne.

Bornschier, S. (2009). Cleavage Politics in Old and New Democracies: A Review of Literature and Avenues for Future Research. Living Reviews of Democracy, vol. 1, issue 1, s.1-13.

Castells, M. (2007). Społeczeństwo sieci. Warszawa: PWN. Clark, T.N., Lipset, S.M. (1991). Are Social Class Dying. International Sociology, 6, s. 397-410.

Clark, T.N., Lipset, S.M., Rempel, M. (1993). The Declining Political Significance of Social Class. International Sociology, 8, s. 293-316.

Dalton, R.J. (1984). Cognitive Mobilization and Partisan Dealignment in Advanced Industrial Democracies. Journal of Politics, 46, s. 264-284.

Dalton, R.J., Flanagan, S.C., Beck, P.A. (red.). (1984). Electoral Change in Advanced Industrial Democracies. Princeton: Princenton University Press.

de Graaf, N.D., Heath, A., Need, A. (2001). Declining Cleavages and Political Choices in Advanced Industrial Democracies. Electoral Studies, 20, s. 1-15.

Doktorowicz, K. (red.). (2002). Społeczeństwo informacyjne: wyzwania dla gospodarki, polityki i kultury. Katowice: Wydawnictwo „Śląsk”.

Elections results - Pennsylvania. (2019). Pobrane z: www.nytimes.com/elections//result/ pennsylvania.

Franklin, M.N. (1985). The Decline of Class Voting in Britain. Nowy Jork: Oxford University Press.

Franklin, M.N., Mackie, T., Valen, H. (eds.). (1992). Electoral Change: Response to Evolving Social and Attitudinal Structures in Western Countries. Nowy Jork: Cambridge University Press.

Inglehart, R. (1977). The Silent Revolution. Princeton: Princeton University Press.

Karvonen, L., Kuhnle, S. (red.). (2001). Party Systems and Voters Alignments Revisited. Londyn-New York: Routledge.

Knutsen, O., (2006). Class Voting in Western Europe. Londyn: Rowman \& LittleField.

Kotowicz-Jawor, J. (red.). (2009). GOW - wyzwanie dla Polski. Warszawa: PTE. Krzysztofek, K., Szczepański, M., (2005). Zrozumieć rozwój. Od społeczeństw tradycyjnych do informacyjnych. Katowice: Uniwersytet Śląski.

Kukliński, A. (red.). (2001). Gospodarka oparta na wiedzy: wyzwanie dla Polski XXI wieku. Warszawa: KBN. Kukliński, A. (red.). (2003). Gospodarka oparta na wiedzy: perspektywy Banku Światowego. Warszawa: Biuro Banku Światowego w Polsce, 
KBN. Lipset, S.M., Rokkan, S., (1967). Party System and Voter Alignments. Cross National Perspective. Nowy Jork: The Free Press.

Mair, P. (1997). The Freezing Hypothesis. An Evaluation. W: L. Karvonen, S. Kuhnle (red.). Party Systems and Voter Alignments Revisited (s. 27-44). Londyn-Nowy Jork: Routledge.

Manza, J., Brooks, C. (1999). Social Cleavages and Political Change: Voter Alignments and US Party Coalitions. Oxford: Oxford University Press.

Moreno, A. (1999). Political Cleavages. Issues, Parties, and the Consolidation of Democracy. Boulder: Westview Press, CO. Nieuwbeerta, P., Ultee, W. (1999). Class Voting in Western Industrialized Countries, 1945-1990: Systemizing and Testing Explanations. European Journal of Political Research, 35, s. 123-160.

Opinion Why Rural America Voted for Trump. (2017). Pobrane z: www.nytimes. com/2017/01/05/opinion/why-rural-america-voted-for-trump.html.

Rokkan, S. (1962). Approaches to Study of Political Participation. Bergen: Michelsen Institute.

Rokkan, S. (1970). Citizens, Elections, Parties. Approaches to the Comparative Study of the Processes of Development. Oslo: Universitetsforlaget.

Rose, R., Urwin, D. (1970). Social Cohesion, Political Parties, and Strains in Regimes. Comparative Political Studies, 18, s. 287-319.

Rural America Lifted Trump to the Presidency Support is Strong but Not Monolithic. (2017). Pobrane z: www.washingtonpost.com/politics/rural-america-lifted-trumpto-the-presidency-support-is-strong-but-not-monolithic/2017/06/16/df4f91564ac9-11e7-9669-250d0b15f83b_story.html.

Scholte, A. (2005). Globalization. A Critical Introduction. Nowy Jork: Palgrave Macmillan.

Szewczyk, A. (red.). (2007). Społeczeństwo informacyjne - problemy rozwoju. Warszawa: Centrum Doradztwa i Informacji Difin.

Trump, D.J. (2016). Remarks at Macomb Community College South Campus in Warren Michigan, 31 october 2016. Pobrane z: www.presidency.ucsb.edu/ws/index. php?pid=122537.

Trump, D.J. (2016). Remarks At Rally At the New Hampshire Sportsplex in Bedford, New Hampshire, 29 września 2016. Pobrane z: www.presidency.ucsb.edu/ws/index. php?pid=119202.

U.S. Census Bureau. (2019). Pobrane z: www.census.gov.

Urban and rural America are becoming increasingly polarized. (2016). Pobrane z: www. washingtonpost.com/grpahics/politics/2016-election/urban-rural-vote-swing/.

Why Trump Won Rural America. (2017). Pobrane z: www.dissentmagazine.org/ online_articles/rural-vote-trump-economy-manufacturing. 